\title{
Describing The Way Of Teaching English To Students With Hearing Impairment
}

\author{
Aditya Pratama, Joko Nurkamto, Endang Setyaningsih \\ English Education Department \\ Teacher Training and Education Faculty \\ Sebelas Maret University of Surakarta
}

E-mail:tamakawaii001@gmail.com

\begin{abstract}
Despite of the numerous researches of English language teaching, there are not many researches about teaching English to students with hearing impairment, thus this research is implemented. The objectives of the research are to: (1) describe the implementation of teaching and learning English in XI grade students of SLB-B in Surakarta (2) identify the problems faced by teacher and students in the process of teaching and learning English, and (3) find out the students' proficiency level in English. This research used qualitative naturalistic method. The data were collected through observation, interview, and document collecting. Coding was used in analyzing the data. The research finding shows that the students with hearing impairment are also able to understand English as long as the teacher uses various teaching method which are suitable with them. The students' problems are coming from of their lack of language input which results in their imperfect pronunciation and limited vocabulary.
\end{abstract}

Keywords: Students with hearing impairment, English proficiency, total communication.

\section{INTRODUCTION}

Nowadays, English is very important in almost every aspect in human's life. Frath (2010: 3) says "English has become the international language of science and technology, commerce and diplomacy, tourism and travel and English is now the first source for information in most languages." Lie (2002: 60) also states "The knowledge of English has become a significant vehicle for accessing valued resources and elite positions." It is emphasized by the fact that the most of the knowledge on which the global communication and economy operate is in English. Since English has important role as global communication and importantly the transfer of science and technology, Indonesian government also has included English in the education system curriculum. English should be learned by all students, not only by normal students, but also the students with special needs. It is based on UUD 1945 pasal 12: Tiap-tiap warga negara berhak mendapatkan pengajaran (Every citizen has the same right to have education). That statement indicates that every citizen including students with special needs has the same right in receiving education.

According to Wah (2011) a child or student is considered to have Special Education Needs if he/she: (1) has a disability, (2) displays greater difficulty in 
learning as compared to the majority of peers of the same age or displays difficulty accessing educational facilities for the majority of peers of the same age, and (3) requires different and/or additional resources beyond what is available.

Wah also states that there are several types of disabilities in the children with Special Education Needs they are students with: visual impairment, hearing impairment, intellectual disability, cerebral palsy, attention deficit hyperactivity disorder, and multiple disabilities.

From all of impairments or disabilities mentioned above, the researcher took interest on the students with hearing impairment. The main point in acquiring language is through hearing, but the students' hearing impairment intrudes the sound that they are able to receive and results in the limited sound, vocabulary and language which they are able to master. It also affecting their speaking skill and results in speech impairment, whereas spoken language is important point in communication. This is the reason why the impairment is a condition of hearing loss which caused an individual unable to receive stimuli, especially from their hearing instrument."

Berryman (2006) states that hearing can be described by the range of sounds one can hear and how softly one can hear such sounds. The range of sound is measured in hertz or number of sound waves per second. The intensity or strength of a sound is given in terms of decibels which usually range from 0 to 140 decibels where 0 decibels represents the quietest level of hearing accessible to the average human ear and 140 decibels, where physical damage immediately occurs. Level of hearing loss by range of sounds one can hear is defined as in Table. 1.

From the definition of the experts above, the researcher draws conclusion that hearing impairment is impairment in their hearing instrument which hinder the ability to perceive or comprehend auditory information and its severity is range from mild to profound according to the range of sounds one can hear.

Table 1. Level of Hearing Loss.

\begin{tabular}{ccc}
\hline Severity & Age less than 15 & Age 15 or more \\
\hline Mild & $0-30 \mathrm{db}$ & $25-44 \mathrm{db}$ \\
Moderate & $31-60 \mathrm{db}$ & $45-64 \mathrm{db}$ \\
Severe & $60-90 \mathrm{db}$ & $>64 \mathrm{db}$ \\
Profound & $>90 \mathrm{db}$ & - \\
\hline
\end{tabular}

researcher took interest to the students with hearing impairment.

"Hearing impairment is defined as a diminished ability to detect, recognize, discriminate, perceive, and/or comprehend auditory information" (Wah 2011: 24). Kartadinata (1996: 74) also states "Hearing
Despite those difficulties faced by the students with hearing impairment, they also have the same right in receiving education. According to Dwidjosumarto (1995), there are two types of formal education system for students with hearing impairment in Indonesia, they are: Integration system and 
Segregation system. Integration system is an education system that gives chance for students with hearing impairment to have education along with normal students in the same school and in the same class. Segregation system is an education system which separate students with hearing impairment with other normal students. In other words, this system gives education program through special education institute for students with special education needs (Anak Luar Biasa) which is called as School for Students with Special Needs (Sekolah Luar biasa). From two types of school mentioned above, the researcher interested to conduct a research in the school with segregation system. The researcher chose this school because this school giving education services to the students with hearing impairment through special methods exclusively for them. The research wanted to know what are the special methods used in this school and how those methods are implemented in the school. Thus, the researcher conducted a research in the segregation school for the students with hearing impairment in Surakarta which is: SLB B in Surakarta. This school is exclusive for students with hearing impairment and one of the special methods in this school is the use of sign language.

From the description above, the researcher encouraged to conduct a qualitative-naturalistic study at eleventh grade students of SLB B in Surakarta. The study is focused on: (1) the implementation of teaching and learning English; (2) the problems faced by the students in learning English; also (3) students' proficiency in English.

\section{RESEARCH METHODS}

The research was conducted at SLB $B$ in Surakarta from September to November 2013. The subjects of the research were the students of eleventh grade and the English teacher. There were three students in this class and teacher SS is the English subject teacher of this class.

In this research, the writer used qualitative approach in the form of naturalistic. According to Mulyana (2003) naturalistic study has assumption that the behavior of a group of people only could be understood through analysis of their natural setting which is not a made up setting like experiment or formal interview. So in this research, the writer collected the data as natural as possible from the natural setting.

According Lofland as cited in Lexy J. Moleong (2010: 157) "The primary data sources in qualitative research are words and activities, and the rest is additional data like documents and others." Based on that, the qualitative sources of data are: documents, series of activity, and informants.

The techniques used by the researcher to collect the data were (1) document collecting: the researcher studied the syllabus, lesson plan and hand out book used in the process of teaching and learning English; (2) participant observation: the researcher came into the class seven times and took position in the side of the class that was taught by Mrs. SS. The purpose was to observe the process of teaching learning activities while taking note of the occurrences in the class; and (3) interviewing: the researcher made interviews with the English teacher of SLB$B$ in Surakarta, Mrs. SS and three of eleventh grade students: DN, LL and YM 
(Moleong: 2010). In analyzing the qualitative data, the researcher used coding which consists of: open coding, axial coding and selective coding (Strauss and Corbin as cited in Kolb 2012).

\section{RESEARCH FINDINGS DISCUSSIONS}

AND

This research has three major findings:

1. The main problem of the students with hearing impairment in learning English comes from the lack of language input. The lack of language input comes from their hearing impairment, also the limited words and language used by the society around the students with hearing impairment. Thus, the lack of language input of the students with hearing impairment results in their imperfect pronunciation and their limited vocabulary mastery.

2. Students with hearing impairment are also able to learn English just like any other students. The 'master-key' is the teacher. As long as the teacher uses various teaching method, materials and media which are suitable with students' condition, then their ability in learning English could be optimized.

3. According to the classification from Gottlieb (2004), the English proficiency level of eleventh grade students of SLB in Surakarta is on level 2-Beginning.

Based on finding number 1 , it could be seen that main problem of the students with hearing impairment in learning English comes from the lack of language input. The lack of language input comes from their hearing impairment, and from the limited words used by other people to communicate with them.

Speech maybe audible to the students with hearing impairment, but the words may not be clearly intelligible for them. Doyle and Dye (2002: 8) state that:

"Speech might be audible to a child with a hearing impairment, but the words may not be intelligible without technological intervention.... When a child is asked if $\mathrm{s} /$ he can hear, the child's likely response will be 'yes,' however, understanding what was said is a different story! For instance 'walk', 'walked', 'walking' and 'walks' may all sound the same, and words like 'vacation' and 'invitation' may be confused. So a child may behave as if $\mathrm{s} /$ he heard and understood what was said, but $\mathrm{s} /$ he would not know if critical sounds were missed."

Children with hearing impairment have difficulty in differentiating words especially words with similar pronunciation. Thus their pronunciation is impaired or imperfect.

In addition, Massaro and Light (2003:

3) stated:

"Children with hearing loss have significant deficits in both spoken and written vocabulary knowledge. One reason is that these children tend not to overhear other conversations because of their limited hearing and are thus shut off from an opportunity to learn vocabulary."

From that statement, it can be concluded that because of their limited hearing, children with hearing impairment tend to miss conversations and any input sounds, thus it resulted in their lack of vocabulary. 
Besides, the researcher also found out that the society gives special treatment to the students with hearing impairment. Since the society knows that those children had hearing impairment, then they tend to use the simplest words possible while
Despite having difficulties in learning English, according to the finding number 2, students with hearing impairment are also able to learn English just like any other students as long as the teacher uses various teaching method, materials and

Table 2. English Language Proficiency Level

Level At English language proficiency, English language learners will process, understand,
produce or use:

\begin{tabular}{|c|c|}
\hline í & $\begin{array}{l}\text { - the technical language of the content areas; } \\
\text { a variety of sentence lengths of varying linguistic complexity in extended oral or written } \\
\text { discourse, including stories, essays, or reports. } \\
\text { oral or written language approaching comparability to that of English proficient peers when } \\
\text { presented with grade level material. }\end{array}$ \\
\hline 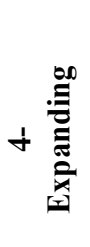 & $\begin{array}{l}\text { - } \\
\text { - a variety of sentence lengths of varying linguistic complexity in oral discourse or multiple, } \\
\text { related paragraphs; } \\
\text { oral or written language with minimal phonological, syntactic, or semantic errors that do not } \\
\text { impede the overall meaning of the communication when presented with oral or written } \\
\text { connected discourse with occasional visual and graphic support. }\end{array}$ \\
\hline m. & $\begin{array}{l}\text { - general and some specific language of the content areas; } \\
\text { - expanded sentences in oral interaction or written paragraphs; } \\
\text { oral or written language with phonological, syntactic, or semantic errors that may impede } \\
\text { the communication but retain much of its meaning when presented with oral or written, } \\
\text { narrative or expository descriptions with occasional visual and graphic support. }\end{array}$ \\
\hline 光 & $\begin{array}{l}\text { - general language related to the content areas; } \\
\text { - phrases or short sentences; } \\
\text { oral or written language with phonological, syntactic, or semantic errors that often impede } \\
\text { the meaning of the communication when presented with one to multiple-step commands, } \\
\text { directions, questions, or a series of statements with visual and graphic support. }\end{array}$ \\
\hline 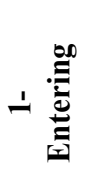 & $\begin{array}{l}\text { - pictorial or graphic representation of the language of the content areas; } \\
\text { - words, phrases, or chunks of language when presented with one-step commands, directions, } \\
\text { WH-questions, or statements with visual and graphic support. }\end{array}$ \\
\hline
\end{tabular}

communicating with students with hearing impairment, thus resulted in the lack of words input and limited vocabulary of the students with hearing impairment. Giving this kind of treatment, results in the limited vocabulary that the children with hearing impairment have. media which are suitable with students' condition.

According to Khurshid, Gilani, Jabbar and Noureen (2003), in teaching learning process, teaching methodology plays a key role. There are different teaching methods for teaching different subjects. 
Selection of any particular teaching method depends upon many factors such as the age and sociolinguistic background of the learners, classroom environment, teachers' competencies, and availability of the audiovisual aids and so on.

From the explanation above, the teacher and school should use suitable method to optimize the process of teaching and learning. SLB B in Surakarta used Komtal/Komunikasi Total or Total Communication Approach which contains various components of communication means in the process of teaching and learning. Suparno (1997) states that there are three principles in Total Communication Approach:

1. It is introduced as early as possible to the children.

2. It involves components such as: gesture, sign language, lip-reading, finger spelling, oral-speaking, reading and writing.

3. Utilization of children's residual hearing through continuous training and with the help of hearing aids.

The students' parents in SLB-B in Surakarta usually have taught their children to use total communication since they were young children, especially how to use sign language. The school also gives the students continuous speaking and listening training by providing education for speech development (bina wicara), and education for rhythm and sound perception (bina persepsi bunyi dan irama). The school also suggests students' parents to provide hearing aids to the students.

Total communication is applied in the process of teaching and learning English in the class between the teacher and students. They used oral speaking as their primary means of communication while adding other components mentioned by Suparno above such as gestures, lip-reading, reading-writing, and sign language as the supporting means of communication. The resource of the sign language used in this school is from SIBI (Sistem Isyarat Bahasa Indonesia) dictionary.

Even though the students could not master pronunciation perfectly, teacher SS, the English teacher of SLB-B in Surakarta still could teach them and optimized their pronunciation. To improve students' pronunciation the teacher trained the students to speak by using drilling method. The teacher gave sentences to the students, then the teacher read it aloud and after that she asked the students to repeat her pronunciation. The teacher emphasized the vowels of the words by using sign language so the students could pronounce the words correctly. If the students pronounced the words incorrectly, she taught them again about how to pronounce it until the students could correctly pronounce the words. The teacher also wrote the correct pronunciation of the English words in Indonesia spelling system. Example:

$$
\begin{gathered}
\text { doctor }=\text { dakte } \\
\text { nurse }=\text { ners } \\
\text { people }=\text { pipel }
\end{gathered}
$$

To improve students' vocabulary, teacher SS introduced approximately ten new words to the students in every new chapter. They discussed the new words together, and then the students could make a note of them and remembered those words at home. The teacher also gave tasks related to those new words to make the students familiar with those words and the words were recalled every meeting. 
After the teacher used suitable approach and used various teaching method and media, the eleventh grade students of SLB B in Surakarta were able to understand the English lesson, enlarged their vocabulary mastery and improve their pronunciation.

The researcher also determined students' English proficiency according to Gottlieb (2004: 6). He mentions five proficiency levels of the English language, as in Table 2.

The classification shows that the IX grade students of SLB-B in Surakarta are able to: 1) understand general language related to the content areas. The students are able to mention words related to the topic given by the teacher, 2) Produce phrases or short sentences. The students are able to produce short sentences but have difficulty in produce long sentences due to their confusion of arranging word orders and their limited vocabulary mastery, and 3) Use oral or written language with some errors that often impede the meaning of communication. The students are able to use oral or written language but sometimes they made some mistakes which hinder the meaning of communication. As for example: One of the students mistake in translating people/orang into kembar because he thought that people $=$ double $=$ kembar .

\section{CONCLUSIONS AND SUGGESTIONS}

The research finding shows that teaching English to the students with hearing impairment is complicated and challenging. Students' hearing and speech impairment results in their imperfect pronunciation and lack of vocabulary. Even so, students with hearing impairment are also able to master and understand English just like any other students as long as the teacher uses various teaching method, materials and media which are suitable with them.

It is suggested for the school of SLB B in Surakarta to provide several hearing aids and lend them to the students with severe hearing impairment but cannot afford to buy a hearing aid. The school also could recruit or hire field-study teachers so the students can get the lesson from the teachers which are specialized in their field of study.

The English teacher is expected to apply various methods and media to improve students' mastery of English. The teacher should not rely only on one reference book. The teacher can use more books and the teacher can search more materials in the internet.

The eleventh grade students of SLBB in Surakarta should know that they are able to learn English regardless their impairment and they should not think that their impairment is a hindrance to learn English. The students should also try to use English in their daily life when communicating with their friends. They can start with simple words or sentences and they can develop it day by day so they can be familiar in using English.

\section{BIBLIOGRAPHY}

Berryman, John. (2006). Listen hear! The economic impact and cost of hearing loss in Australia. Melbourne: Access Economic Pty Ltd

Doyle, Melanie., \& Dye, Linda. (2002). Mainstreaming the student who is 
deaf or hard-of-hearing. San Diego: CCHAT Center

Dwidjosumarto, Andreas. Ortopedagogik: Anak tunarungu. Bandung: Departemen Pendidikan dan Kebudayaan.

Frath, Pierre. (2010). Should the world rely on English as a lingua franca? Champagne-Ardenne: Université de Reims Champagne-Ardenne.

Gottlieb, Margo. (2004). Illinois English language proficiency standards for English language learners (K-12). Chicago, Illinois: Division of English Language Learning.

Kartadinata, Sunaryo. (1996). Pendidikan anak luar biasa. Jakarta: Departemen Pendidikan dan Kebudayaan.

Khurshid, Khalid.,Gilani Iram. G., Jabbar, Abdul., \& Noureen Shazia. (2003). A study of the perception of teachers regarding suitable method of teaching English at secondary level. Multan: Journal of Elementary Education.

Kolb, Sharon. M. (2012). Grounded theory and constant comparative method: Valid research strategies for educators. Whitewater: University of Wisconsin-Whitewater.

Lie, Anita. (2002). English curriculum in multicultural societies. Surabaya: Journal of Southeast Asian Education.

Massaro, Dominic.W., Light, Joanna. (2003). Improving the vocabulary of children with hearing loss. Santa Cruz: University of California.
Moleong, Lexy.J. (2010). Metodologi penelitian kualitatif. Bandung: PT. Remaja Rosdakarya.

Mulyana, Deddy. (2003). Metodologi penelitian kualitatif. paradigma baru ilmu komunikasi dan ilmu sosial lainnya. Bandung: PT Remaja Rosdakarya.

Suparno. (1997). Komunikasi Total. Yogyakarta: Institut Keguruan dan Ilmu Pendidikan Yogyakarta.

Undang-Undang Dasar Negara Republik Indonesia Tahun 1945.

Wah, Sum C. (2011). Psycho educational assessment \& placement of students with special education needs. Ministry of Education, Singapore. 